\section{Bioactive Glass Particles in Two-Dimensional and Three- Dimensional Osteogenic Cell Cultures}

Luciana B. Alves ${ }^{1}$, Sérgio L. S. de Souza ${ }^{2}$, Mario Taba Jr. ${ }^{2}$, Arthur B. Novaes

Jr. $^{2}$, Paulo T. de Oliveira ${ }^{3}$, Daniela B. Palioto ${ }^{2}$

\author{
'Department of Integrated \\ Clinic, School of Dentistry, \\ UFBA - Universidade Federal da \\ Bahia, Salvado, BA, Brazil \\ ${ }^{2}$ Department of Oral Surgery and \\ Periodontology, School of Dentistry of \\ Ribeirão Preto, USP - Universidade de \\ São Paulo, Ribeirão Preto, SP, Brazil \\ ${ }^{3}$ Department of Morphology, \\ Stomatology and Physiology, \\ School of Dentistry of Ribeirão \\ Preto, USP - Universidade de São \\ Paulo, Ribeirão Preto, SP, Brazil
}

Correspondence: Luciana Bastos Alves, Avenida Araújo Pinho, 62, Canela 40110-150 Salvador, BA, Brazil. Tel: +55-71-32838970. Fax: +55-71-3336-5776. E-mail: luciana.bastos@ufba.br

Key Words: osteogenic cells, bioactive glass, threedimensional culture, collagen.

\section{Introduction}

Osteogenic cell culture systems are routinely used to study the tightly regulated cellular and extracellular matrix events of bone formation in a controlled environment. A commonly used system to study bone formation in vitro is the primary culture of rat calvaria osteogenic cells (well characterized as an abundant source of osteoblasts and committed osteoprogenitor cells). Cell isolation procedures, culture conditions, the temporal sequence of osteoblastic differentiation and expression of matrix proteins have been well defined for this system. The expression pattern of matrix proteins in vitro has been correlated with acquisition and maturation of the osteoblast phenotype (1).

In vitro studies on osteogenesis and matrix formation are frequently based on two-dimensional (2D) cultures. However, there are well-established differences between cells grown in 2D culture and a three-dimensional (3D) environment (2). Researchers have been trying to make appropriate scaffolds for cell implantation to simulate the 3D environment in vivo. Collagen is the most useful biomaterial that has been used for tissue engineering purposes, due its excellent biocompatibility and safety associated with its biological characteristics, such as biodegradability and weak antigenicity materials in the cells (3).

Bioactive glass (BG) is a bone repairing material that promotes bone growth in vivo for implantation. The enhanced bone growth induced by BG results in a multistage mechanism that begins as the glass gets in contact with physiological fluids and this release is believed to stimulate osteogenesis. There is evidence that the ionic products of BG enhance osteoblast attachment, proliferation, differentiation and mineralization, and also induce differentiation of bone marrow stromal cells (4).

It is reasonable to suggest that the $3 \mathrm{D}$ collagen and BG particles could have a similar effect on osteogenic cells derived from newborn rat calvaria. This study focused on evaluating the effect of BG particles on osteogenic cells behavior cultured on 2D and 3D collagen gel. It also aimed to establish whether the three-dimensionality, collagen and ionic product of BG particles could induce these cells to an osteoblastic phenotype.

\section{Material and Methods}

The osteogenic cells derived from newborn rat calvaria were seeded on 3D scaffolds with $B G$ particles $(3 D+B G)$ and without particles (3D); $2 \mathrm{D}$ collagen surface with $B G$ particles (2D+BG) and without particles (2D); and on plastic coverslip Thermanox ${ }^{\mathrm{TM}}$ (Thermo Fisher Scientific, Nunc, NY, USA) (control).

\section{Preparation of Scaffolds}

3D scaffolds were prepared by mixing the collagen solution ( $3 \mathrm{mg} / \mathrm{mL}$, bovine Col I) (BD BioSciences, San Jose, 
$\mathrm{CA}$, USA) with a mixture solution of $1 \mathrm{M}$ of $\mathrm{NaOH}, 186 \mathrm{mM}$ $\mathrm{NaHCO}_{3}$ and $\alpha$-minimum essential medium ( $\alpha$-MEM) (Gibco Invitrogen, Carlsbad, CA, USA) with a final concentration of $2 \mathrm{mg} / \mathrm{mL}$. Then, $250 \mu \mathrm{L}$ of collagen solution were placed in each well containing a plastic coverslip (24-well plate) (Corning Incorporated, Corning, NY, USA) and maintained in an incubator under a humidified atmosphere of $5 \% \mathrm{CO}_{2}$ in $95 \%$ air at $37^{\circ} \mathrm{C}$ for $15 \mathrm{~min}$, until the solution solidified into a collagen gel matrix. After polymerization, samples were $15.8 \mathrm{~mm}$ in diameter and $2 \mathrm{~mm}$ high.

$2 \mathrm{D}$ surfaces were prepared by diluting the collagen on Phosphate Buffered Saline (PBS) (Gibco Invitrogen) to achieve the final concentration of $50 \mu \mathrm{L} / \mathrm{mg}$. After that, 100 $\mu \mathrm{L}$ of collagen dilution were placed in each well containing a plastic coverslip (24-wells plate) and maintained at room temperature (RT) for $1 \mathrm{~h}$. After this the remaining solutions were aspirated.

The BG particles (Biogran ${ }^{\circledR}$, Biomet 3i, Palm Beach Gardens, FL, USA) were seeded at $30 \mu \mathrm{g} /$ well $3 \mathrm{D}+\mathrm{BG}$ and $2 D+B G$, before the gel polymerization and the collagen $2 \mathrm{D}$ drying. For the control surfaces a coverslip was used, considering the need to remove the film for immunofluorescence analysis.

\section{Cell Isolation and Primary Culture of Osteogenic Cells}

Osteogenic cells were isolated by sequential trypsin/ collagenase digestion of calvarial bone from newborn (2-4 days) Wistar rats, as previously described (17-20). Cells were seeded by overlay method on different groups at a density of $2 \times 10^{4}$ cells per well for periods of up to 14 days in $1 \mathrm{~mL}$ of osteogenic medium $\alpha$-MEM supplemented with $10 \% \mathrm{FBS}, 0.3 \mathrm{mg} / \mathrm{mL}$ fungizone, $50 \mu \mathrm{g} / \mathrm{mL}$ gentamycin, $5 \mu \mathrm{g} / \mathrm{mL}$ of ascorbic acid (Gibco, Invitrogen) and $7 \mathrm{mM}$ $\beta$-glycerophosphate (Sigma, St. Louis, MO, USA) and dexamethasone $10^{7}$ (Sigma) and maintained in a humidified atmosphere with $5 \% \mathrm{CO}_{2}$ and $95 \%$ air at $37^{\circ} \mathrm{C}$. The culture medium was changed every 2- 3 days. All animal procedures were in accordance with guidelines of the Animal Research Ethics Committee from the Dental School of Ribeirão Preto, Universidade de São Paulo, SP, Brazil.

\section{Cell Viability}

Cell viability was evaluated by 3-[4,5-dimethylthiazol2-yl]-2,5-diphenyltetrazolium bromide (MTT) (Sigma) assay at 3, 7 and 10 days (5). Cells were incubated with $10 \% \mathrm{MTT}(5 \mathrm{mg} / \mathrm{mL})$ in culture medium at $37^{\circ} \mathrm{C}$ for $4 \mathrm{~h}$. The medium was then aspirated from the well, and $1 \mathrm{~mL}$ of acid isopropanol (0.04 NHCl in isopropanol) was added to each well.

The plates were then stirred on a plate shaker for $5 \mathrm{~min}$, and $200 \mu \mathrm{L}$ of this solution was transferred to a 96-well format using opaque-walled transparent-bottomed plates
(Fisher Scientific, PA, USA). Optical density was read at 570 $\mathrm{nm}$ on the plate reader ( $\mu$ Quant Biotek Instruments, VT, USA) and data were expressed as absorbance.

\section{Alkaline Phosphatase Activity}

Alkaline phosphatase (ALP) activity was assayed as the release of thymolphthalein from thymolphthalein monophosphate by using a commercial kit (Labtest Diagnostica, Lagoa Santa, MG, Brazil). Briefly, $50 \mu \mathrm{L}$ of thymolphthalein monophosphate were mixed with 0.5 $\mathrm{mL}$ of $0.3 \mathrm{M}$ diethanolamine buffer, $\mathrm{pH} 10.1$ and left for 2 $\min$ at $37^{\circ} \mathrm{C}$. The solution was then added to $50 \mu \mathrm{L}$ of the lysates obtained from each well for $10 \mathrm{~min}$ at $37{ }^{\circ} \mathrm{C}$. For color development, $2 \mathrm{~mL}$ of $0.09 \mathrm{M} \mathrm{Na}_{2} \mathrm{CO}_{3}$ and $0.25 \mathrm{M} \mathrm{NaOH}$ were added. After $30 \mathrm{~min}$, absorbance was measured using a spectrophotometer ( $\mu$ Quant Biotek Instruments) at 590 $\mathrm{nm}$ and ALP activity was calculated from a standard curve using thymolphthalein to give a range from 0.012 to 0.4 $\mu \mathrm{mol}$ thymolphthalein $/ \mathrm{h} / \mathrm{mL}$. Data were expressed as ALP activity normalized by total protein content (modification of the Lowry method)(6).

\section{Indirect Immunofluorescence for Localization of Bone Sialoprotein (BSP) and Osteopontin (OPN)}

At 7 and 14 days, cells were fixed for $10 \mathrm{~min}$ at RT using $4 \%$ paraformaldehyde in $0.1 \mathrm{M}$ phosphate buffer (PB), pH 7.2. After washing in $\mathrm{PB}$, they were processed for immunofluorescence labeling. Briefly, cells were permeabilized with $0.5 \%$ Triton X-100 in PB for $10 \mathrm{~min}$ followed by blocking with 5\% skimmed milk in $\mathrm{PB}$ for 30 min. Primary monoclonal antibodies to BSP (anti-BSP, 1:200, WVID-9C5) (Developmental Studies Hybridoma Bank, lowa, USA) and OPN (anti-OPN, 1:800, MPIIIB10-1) (Developmental Studies Hybridoma Bank, lowa City, IA, USA) were used, followed by a mixture of Alexa Fluor 594 (red fluorescence)- conjugated goat anti-mouse secondary antibody (1:200) (Molecular Probes, Invitrogen), and Alexa Fluor 488 (green fluorescence)-conjugated phalloidin (1:200) (Molecular Probes, Invitrogen) for $50 \mathrm{~min}$ at RT in a humidified environment, for the detection of actin cytoskeleton and cell periphery. Replacement of the primary monoclonal antibody with PB was used as control. All antibody incubations were performed in a humidified environment for $60 \mathrm{~min}$ at RT. Between each incubation step, the samples were washed three times ( 5 min each) in PB. Before mounting for microscope observation, samples were briefly washed with $\mathrm{dH}_{2} \mathrm{O}$ and cell nuclei stained with DAPI (1:300) (Molecular Probes, Invitrogen) for 5 min. Then the coverslip containing 3D collagen gel, 2D collagen and the control were placed carefully face down on glass slides and mounted with Vectashield antifade (Vector Laboratories, Burlingame, CA, USA). The control 
and two-dimensional samples were then examined under epifluorescence using a Leica DMLB light microscope (Leica, Bensheim, Germany), with N Plan (X10/0.25, X20/0.40) and HCX PL Fluotar (X40/0.75) objectives, outfitted with a Leica DC 300F digital camera, 1.3 Megapixel CCD. The acquired digital images were processed with Adobe Photoshop software (version 7.0) (Adobe Systems Inc., San Jose, CA, USA). The three-dimensional samples were examined under confocal microscopy (Leica TCS-SP2 SE laser scanning system).

\section{Gene Expression Analysis Using Real-Time PCR}

At 7 days gene expression of Alkaline phosphatase (ALP), Osteopontin (OPN), Osteocalcin (OC), Collagen I (COLI) and Runt-related transcription factor 2 (RUNX2) were measured, which characterize the osteoblast phenotype. For analyses of gene expression the plating density was $4 \times 104$ cells/well on the three-dimensional scaffolds. $\beta$-actin (ACTB) was evaluated as control for constitutive gene expression. The gene expression analysis was performed by real-time PCR as described below.

Total RNA was isolated using the TRIZOL ${ }^{\circledR}$ reagent (Gibco, Invitrogen) according to the manufacturer's instructions. The concentration of RNA was determined by optical density at a wavelength of $260 \mathrm{~nm}$, using the GeneQuant (Amersham Biosciences, NJ, USA). The RNA purity was determined from A260/A280 (System for RT-PCR) (Invitrogen). Complementary DNA (cDNA) was synthesized using $1 \mu \mathrm{g}$ of RNA by a reverse transcription reaction (High-capacity cDNA Reverse Transcription Kits; Applied Biosystems, Foster City, CA, USA). Real-time PCR quantitative mRNA analyses were performed in CFX96 (Bio-Rad, Hercules, CA, USA) using SybrGreen system (Applied Biosystems). SybrGreen PCR MasterMix, specific primers and $2.5 \mathrm{ng}$ of cDNA were used in each reaction. The standard PCR conditions were $50{ }^{\circ} \mathrm{C}(2 \mathrm{~min}), 95^{\circ} \mathrm{C}(10$ $\min$ ) and 40 cycles of $15 \mathrm{~s}$ at $95{ }^{\circ} \mathrm{C}$, and a final cycle of 20 min with increasing temperature from $60{ }^{\circ} \mathrm{C}$ to $95^{\circ} \mathrm{C}$, followed by the standard denaturation curve. The used primer sequences are in Table 1.

Each assay was run in triplicate. For mRNA analysis, the relative level of gene expression was calculated in reference to both $\beta$-actin expression in the sample and its respective control using the cycle threshold (Ct) method (7).

\section{Mineralized Bone-Like Nodule Formation and Calcium Content}

At 10 and 14 days, cultures were fixed with $4 \%$ formaldehyde in $\mathrm{PB}, \mathrm{pH} 7.2$, for $2 \mathrm{~h}$ at $\mathrm{RT}$ and washed in the same buffer. The samples were then dehydrated in a graded series of alcohol and stained with 2\% Alizarin red $\mathrm{S}$ (Sigma), pH 4.2, for $8 \mathrm{~min}$ at RT. They were imaged by epifluorescence microscopy. The quantification of color was evaluated by colorimetric method (8). The absorbance was measured on a spectrophotometer ( $\mu$ Quant Biotek Instruments) at a wavelength of $405 \mathrm{~nm}$. The mineralized matrix formation was expressed as optical density.

\section{Statistical Analysis}

Data presented in this work were a pool of three separate experiments in established cell cultures. All experiments were carried out in quintuplicate $(n=5)$, with the exception of real-time RT-PCR, which was done in triplicate $(n=3)$. Nonparametric data were submitted to Kruskal-Wallis test for independent samples, followed by Dunn test for multiple comparisons. Parametric data were submitted to one-way analysis of variance (ANOVA) followed by a Tukey's test, which was used for multiple comparisons. SigmaStat program (version 3.5) (Statcon, Witzenhausen, Germany) was used and a p-value of $<0.05$ was considered statistically significant.

\section{Results}

\section{Cell Viability}

Cell viability results are illustrated in Figure 1. All groups showed a time dependent increase in viability rate over the studied time. MTT assay showed that cell viability was negatively affected by the $3 \mathrm{D}$ culture and $\mathrm{BG}$ particles at 7 days. Cultures on $3 \mathrm{D}+\mathrm{BG}$ produced a decreased rate of cell viability in comparison with the control and $2 \mathrm{D}+\mathrm{BG}$ surfaces $(p<0.05)$. However, at the same time the BG particles enhanced the cell viability on 2D+BG cultures (Fig. 1A).

Table 1. Primer sequences for real-time polymerase chain reaction

\begin{tabular}{|c|c|c|}
\hline Genes & \multicolumn{2}{|c|}{ Primer sequences } \\
\hline \multirow{2}{*}{$\beta$-actin } & Forward & 5'-TGGGTATGGAATCCTGCTGC-3' \\
\hline & Reverse & 5'-CAGCTCAGTAACAGTCCG-3' \\
\hline \multirow{2}{*}{ Runx2 } & Forward & 5'-GAACTGATAGGACGCTGACGA-3' \\
\hline & Reverse & 5'-GCTTCTCCAACCCACGAATG-3' \\
\hline \multirow{2}{*}{ COL I } & Forward & 5'-TCCTGCCGATGTCGCTATC-3' \\
\hline & Reverse & 5'-CAAGTTCCGGTGTGACTCGTG-3' \\
\hline \multirow{2}{*}{ ALP } & Forward & 5'-CGAGCAGGAACAGAAGTTTGC-3' \\
\hline & Reverse & 5'-TGGCCAAAAGGCAGTGAATAG-3' \\
\hline \multirow{2}{*}{ OPN } & Forward & 5'-GCCTGTTCGGCCTTGCCTCCTGTCT-3' \\
\hline & Reverse & 5'-TCAGTCCGTAAGCCAAGCTATCACC-3' \\
\hline \multirow{2}{*}{ OC } & Forward & 5'-GCAGACACCATGAGGACCCT-3' \\
\hline & Reverse & 5'-CCAGAGTCTATTCACCACCTTACTG-3' \\
\hline \multirow{2}{*}{ BSP } & Forward & 5'-СТАСТTTTATССТССТССТCTGAAACGGTT-3' \\
\hline & Reverse & 5'-GCTAGCGGTTACCCCTGAGA-3' \\
\hline
\end{tabular}




\section{Alkaline Phosphatase Activity}

At 7 days the highest levels of ALP activity were observed in cells on $B G$ cultures, which on $2 D+B G$ and $3 D+B G$ was significantly higher than on $2 \mathrm{D}$ and $3 \mathrm{D}(\mathrm{p}<0.05)$. Also, a statistic difference was observed when $3 \mathrm{D}+\mathrm{BG}$ cultures were compared with the control $(p<0.05)$. At 14 days the lowest levels of ALP activity were observed on $3 D$ and $3 D+B G$, and it was significantly different for $2 D(p<0.05)$ and 2D+BG ( $<<0.05)$ (Fig. 1D).

Indirect Immunofluorescence for Location of Bone Sialoprotein (BSP) and Osteopontin (OPN)

On two-dimensional and control surfaces, the cells were spindle shape, with an organized cytoskeleton and defined actin stress fibers. A denser cell layer was observed, indicating that cell proliferation occurred and positive immunolocalization for OPN and BSP was observed. OPN immunolabeling was seen mainly through perinuclear deposits (Figs. 2A and 2B) and BSP as points in the cytoplasm and also in some perinuclear areas (Figs. 2D and 2E). There was also no relationship between this labeling and $B G$ particles (Figs. 2C and 2F). On three-dimensional cultures the cells showed a fusiform and elongated shape, also with

(A)

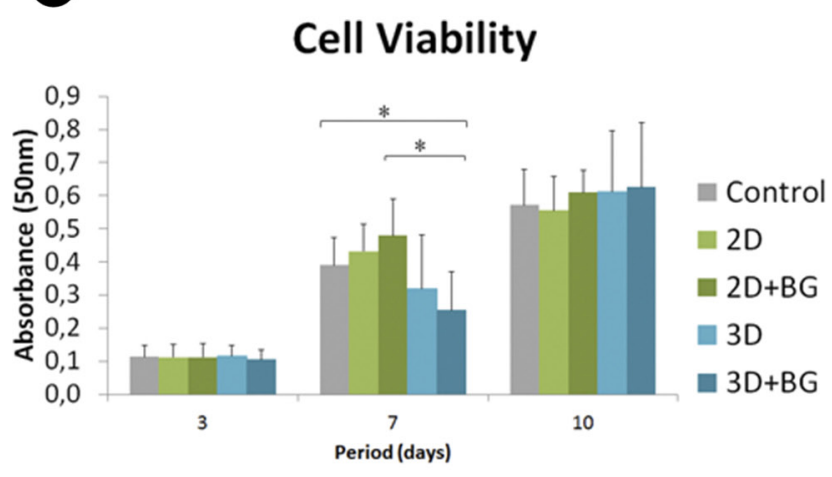

C

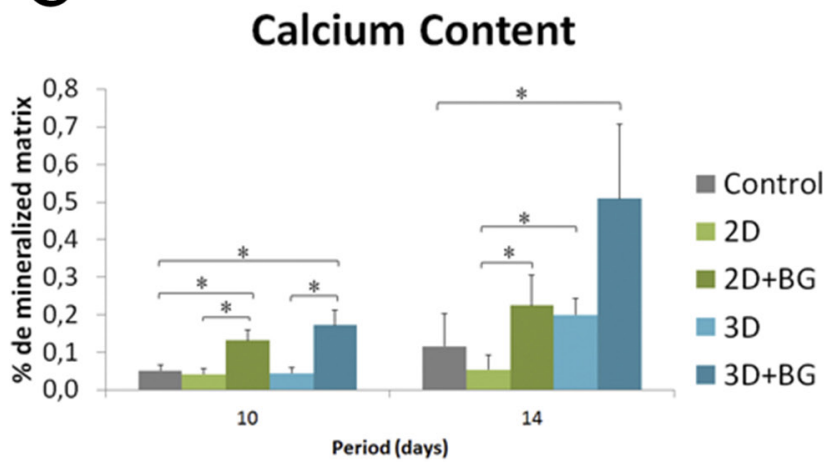

Immunolabeling for OPN and BSP has been viewed mostly around the cell nucleus on 3D (Figs. $3 \mathrm{~A}$ and $3 \mathrm{C}$ ), but it could not be seen in cells on $3 D+B G$. A positive immunolabeling for these proteins was seen on the BG particles (Figs. 3B and 3D).

\section{Gene Expression Analysis Using Real-Time PCR}

The expression levels of ALP, COL I and RUNX2 were upregulated in cells cultured on $3 \mathrm{D}$ and $3 \mathrm{D}+\mathrm{BG}$ compared with those on control surface, however it was not statistically significant. The BG particles showed a positive influence in the levels of OPN, BSP and OC mRNA in the cells cultured on $2 \mathrm{D}+\mathrm{BG}$, compared with $2 \mathrm{D}$ (Fig. 4).

The expression level of $\mathrm{COL}$ I was significantly higher among cells cultured on $3 \mathrm{D}+\mathrm{BG}$ than those on $2 \mathrm{D}+\mathrm{BG}$, where the OPN and OC mRNA levels were significantly higher than on $2 \mathrm{D}$ and $3 \mathrm{D}+\mathrm{BG}$. The cells cultured on $2 \mathrm{D}, 3 \mathrm{D}$ and $3 \mathrm{D}+\mathrm{BG}$ also showed the downregulated level expression of OPN and OC compared with those on the control surface (Fig. 4).

\section{Mineralized Bone-Like Nodule Formation and Calcium Content}

At 10 and 14 days all groups exhibited areas stained with Alizarin red. These areas were more extensive on
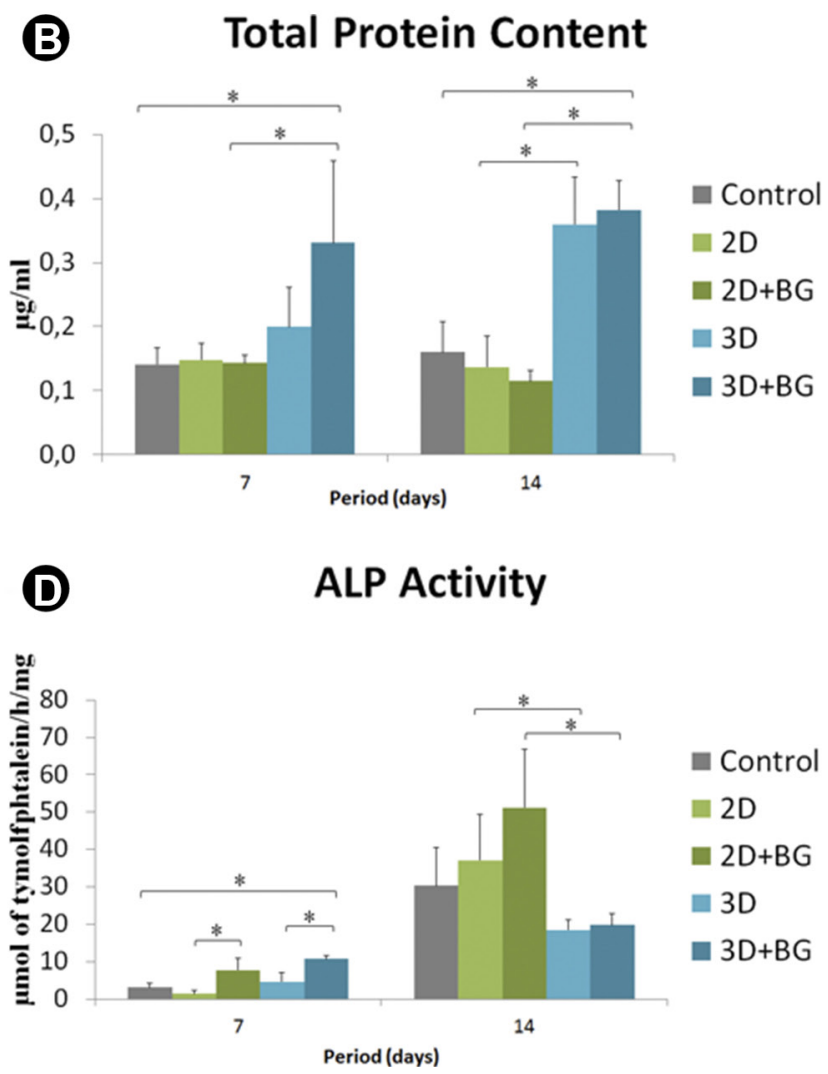

Figure 1. A: Cell viability $\left(m_{ \pm}{ }_{ \pm} S D\right)$ at 3, 7 and 10 days; B: Total protein content (mean \pm SD) at 7 and 14 days; C: Calcium content (mean \pm SD) at 10 and 14 days; D: ALP Activity (mean \pm SD) at 7 and 14 days. ${ }^{*} \mathrm{p}<0.05$ (Kruskal-Wallis-Pos-test Dunn’s) and **p<0.05 (ANOVA; Tukey’s post-test) 
cultures containing BG particles, but by microscopy they were not necessarily seen in the vicinity of the particles (Fig. 5). The quantitative analysis showed better results of calcified matrix formation on BG cultures at 10 and 14 days. At 10 days the amount of calcium in 3D+BG was significantly higher than on the control surface, and it was also greater on $2 D+B G$ than in $3 D, 2 D$ and control. At 14 days calcium content was significantly higher on $B G$ cultures $(2 D+B G$ and $3 D+B G)$ than the control and $2 D$ surfaces (Fig. 1C).
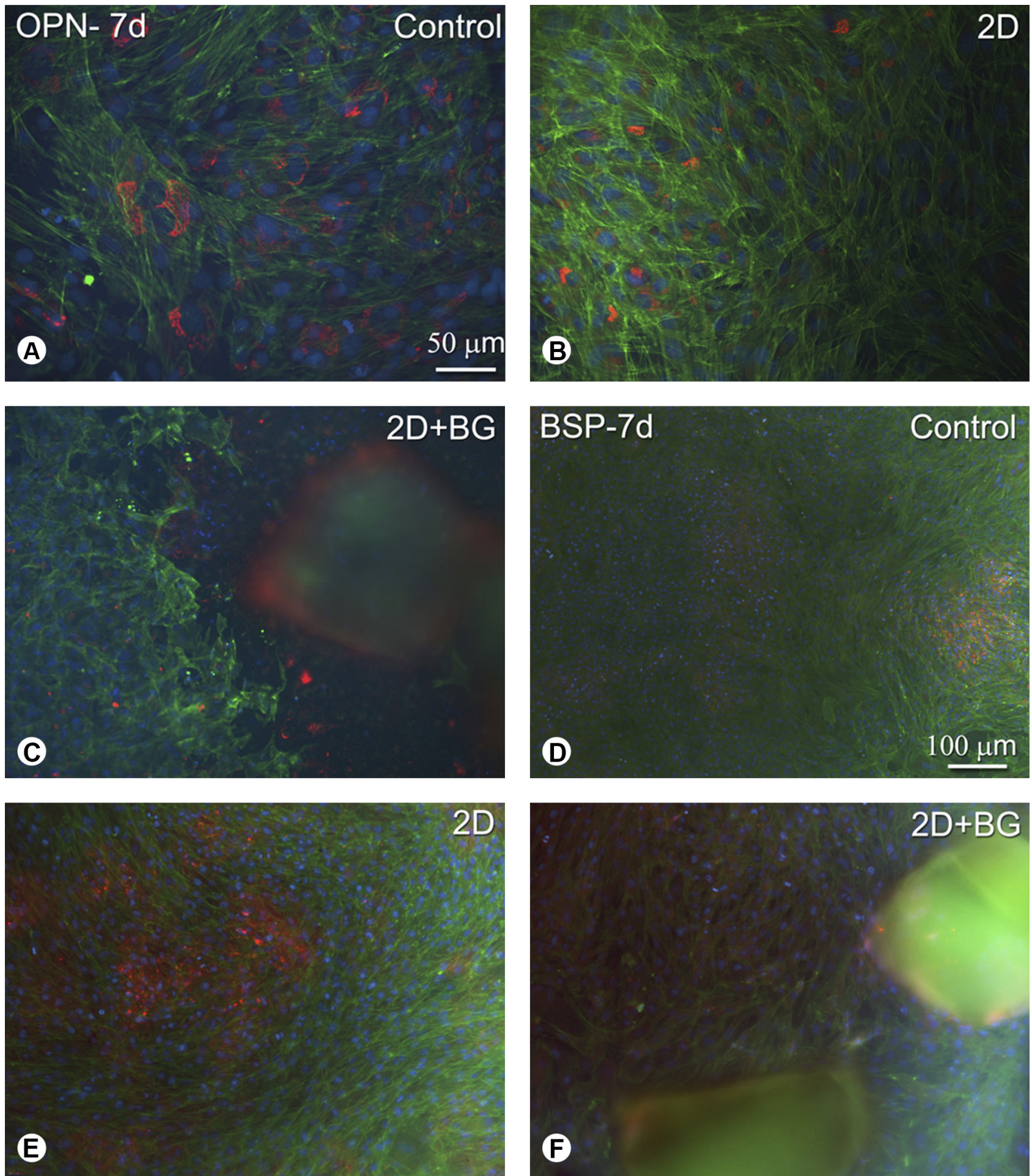

Figure 2. Osteogenic cells grown on different two-dimensional surfaces (control, 2D and 2D+BG) at 7 days. Epifluorescence of actin cytoskeleton labeling (phalloidin labeling, green fluorescence), DNA stain (DAPI, blue fluorescence), OPN (A-C) and BSP (D-F) red fluorescence. Bar A-C: 50 $\mu \mathrm{m}$ and Bar D-F: $100 \mu \mathrm{m}$. 


\section{Discussion}

The present study confirmed that three-dimensional collagen and bioactive glass particles supported cell viability and favored ALP activity, mineralized nodule formation and osteoblastic phenotype expression of osteogenic cells derived from newborn rat calvaria.

The cell viability rate showed an increase of $2 \mathrm{D}$ and $3 D$ collagen with or without BG up to 10 days, showing a normal proliferative index in all evaluated groups, although the three-dimensionality interfered in the viability rate at 7 days. This agrees with another study (9) and could be explained by the organization and maturation of the extracellular matrix surrounding osteoblasts in this time (10). So, at 10 days, cultures on 3D and 3D+BG produced an increased rate of cell viability. It may be explained by the disruption of the extracellular matrix surrounding osteoblasts by the collagen contraction and remodeling, a result of the action of proteolytic enzymes secreted primarily by cells, which may have contributed positively to the cell proliferation in this time. This contraction of the collagen complex at day 14 is consistent with the observations of another study (11). BG particles enhanced
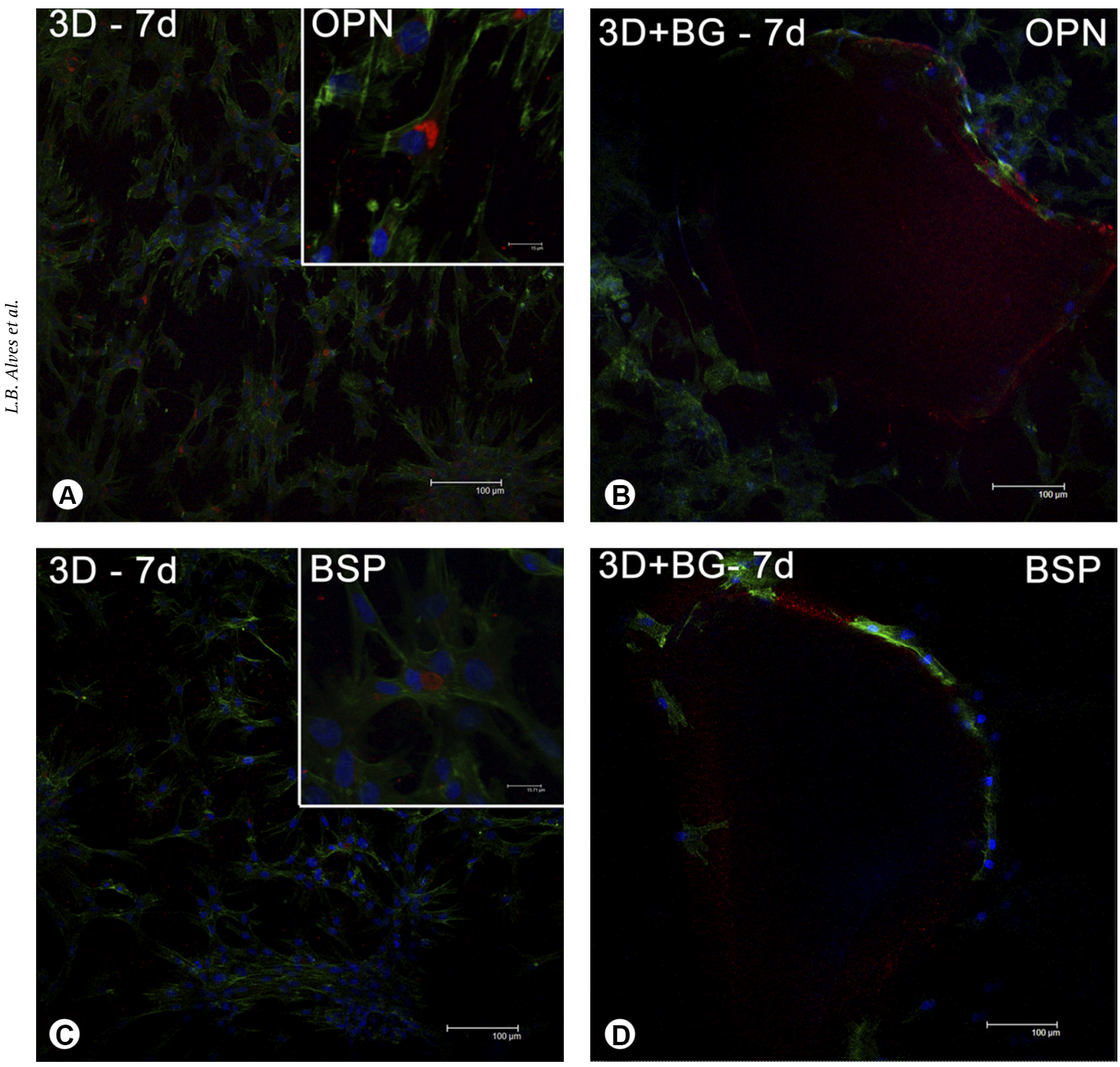

Figure 3. Osteogenic cells grown on different three-dimensional surfaces (3D and 3D+BG) at 7 days. Fluorescence of actin cytoskeleton labeling (phalloidin labeling, green fluorescence), DNA stain (DAPI, blue fluorescence), OPN (A-B) and BSP (C-D) red fluorescence observed in confocal microscopy. 
the cell viability rate on $2 \mathrm{D}+\mathrm{BG}$ cultures at 7 and 10 days, similar to other in vivo study (12). However, significant differences were not observed between the groups at the other evaluated periods.

The higher levels of ALP activity were observed for cells on BG cultures at 7 days, suggesting a positive influence of BG particles, according to other study (4). On the other hand, at 14 days the lowest levels of ALP activity were observed on $3 \mathrm{D}$ and $3 \mathrm{D}+\mathrm{BG}$, which differs from another study (11). This may be explained because osteoblastic progenitor cells in earlier stages of development express greater ALP activity than cells in the later mineralization stage (13). The hypothesis is a that at 7 days, the still stable and intact three-dimensional collagen and cells embedded in the collagen gel are surrounded by the collagen network that creates a biochemical confinement
ALP
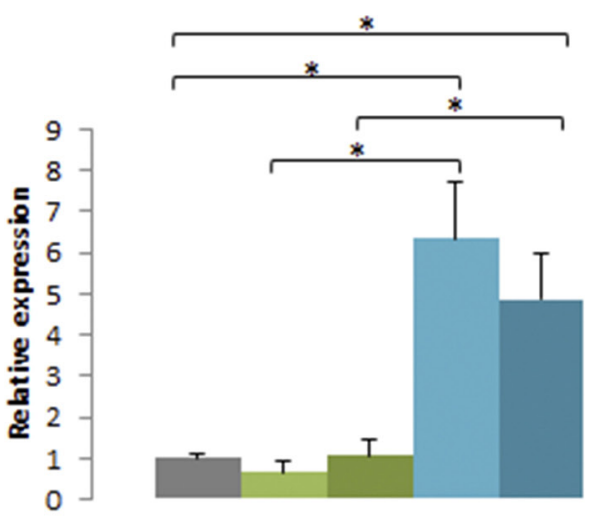

RUNX2
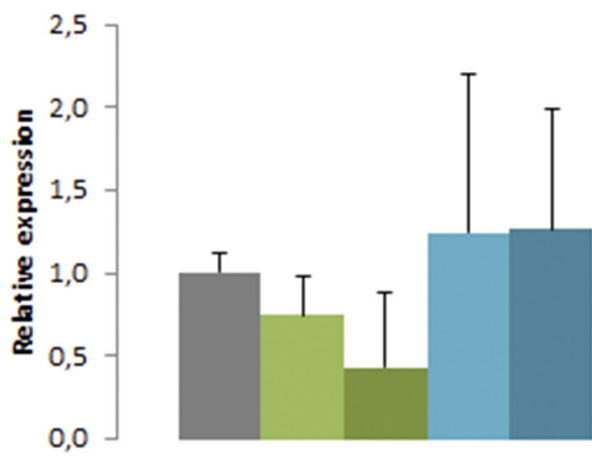

OC

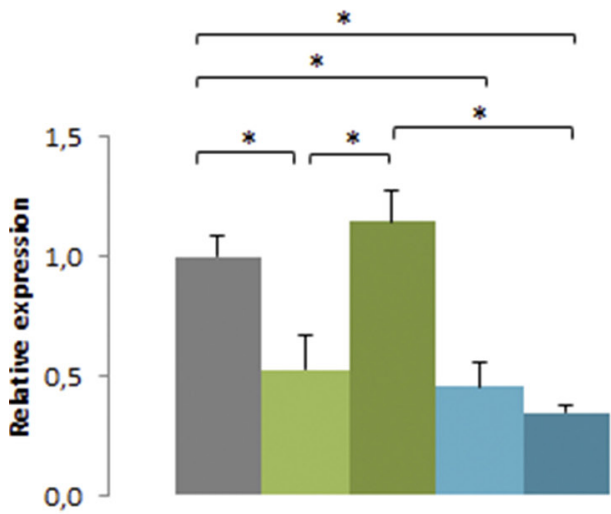

COL I
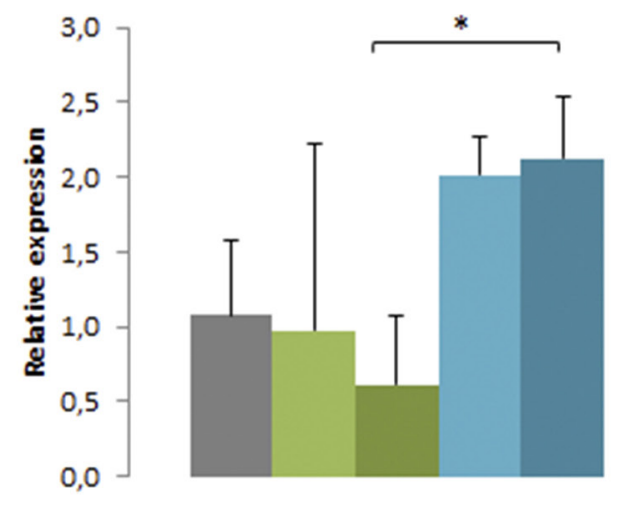

BSP

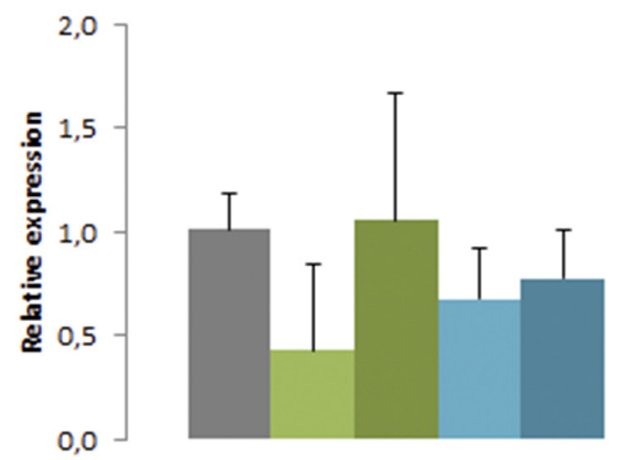

control

$\square 2 \mathrm{D}$

- $2 \mathrm{D}+\mathrm{BG}$

a 30

- $3 \mathrm{D}+\mathrm{BG}$

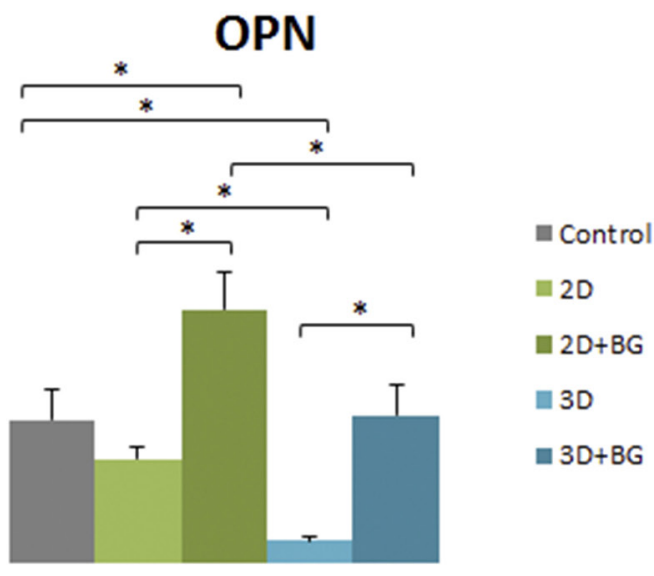

Figure 4. Gene expression of ALP, COL I, Runx2, BSP, OC and OPN in osteogenic cells cultured in different groups at 7 days using real-time PCR. Data were calculated as the relative expression of the target mRNA normalized to $\beta$-actin and to control (calibrator) and are reported as mean \pm SD. * $\mathrm{p}<0.05$ (Kruskal-Wallis; Dunn's post-test). 

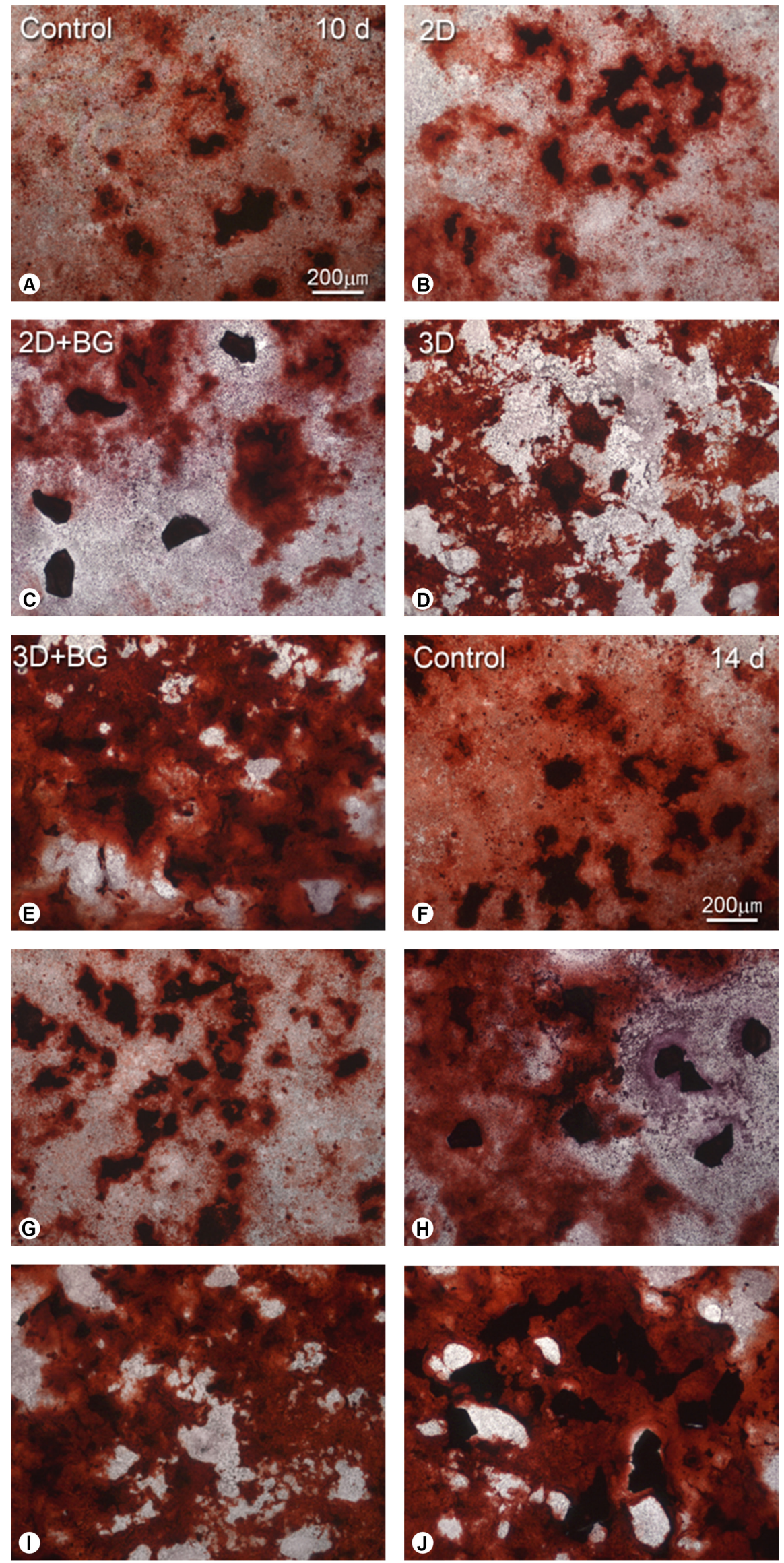

Figure 5. Alizarin red staining showing limited amounts of mineralized nodule formation in osteogenic cultures. Control (A and F), 2D (B and G), 2D+BG (C and H), 3D (D and I) and 3D+BG (E and J). Bar: $200 \mu \mathrm{m}$. 
(14), which could interfere in the ALP activity, but not in the ALP gene expression. This could be explained by the stages of osteoblast differentiation: proliferation, matrix production, ALP expression and mineralization.

A time sequence in gene expression has been clearly established during bone formation (1). In the present study, the expression levels of ALP, COL I and RUNX2 were upregulated in cells cultured on $3 \mathrm{D}$ and $3 \mathrm{D}+\mathrm{BG}$ compared with those on the control surface. These observations are consistent with other studies, using primary human osteoblasts in static 3D culture conditions, which demonstrated an upregulation of COL I, ALP $(15,16)$ and RUNX2 $(2,9)$ in osteoblastic cells cultured in 3D environments, as compared to those cultured in 2D. On the contrary, there are also data reporting a downregulation of COL I and ALP in human osteoblast 3D cultures, compared to monolayer, after 7 and 14 days without osteogenic induction (17). In rat calvaria-derived osteoblast cultures, the cells show an initial peak of OPN mRNA expression in early culture times, followed by a second major peak of expression when the cultures begin to mineralize (1). The study results demonstrated a positive influence of BG particles in the expression levels of OPN, BSP and OC in the cells cultured on $2 \mathrm{D}+\mathrm{BG}$ compared with $2 \mathrm{D}$, agreeing with the literature (18). A negative influence of the three-dimensionality on expression pattern OC, similar to another study (19), was also observed. This also differs from reports about osteoblasts cultured on 3D scaffolds, which showed an increased expression of OPN (20). Using confocal microscopy, were identified discrete patterns of intracellular OPN and BSP staining, with some variations seen in individual cells. These staining patterns suggested the presence of osteoblastic phenotype, but their biological significance is unknown up to now.

The role of isolated active osteoblasts in the process of matrix mineralization in vitro is still unclear. In the present study, quantified alizarin red staining demonstrated calcium deposits in the matrix by colorimetric method (8) at 10 and 14 days. Calcium deposits were significantly greater on cultures with $B G(2 D+B G$ and $3 D+B G)$, even though no close relationship between the mineralized nodules and the particles was observed. This may be explained because the alizarin red assay stained the new mineralized bone particles and the BG itself. The BG particles have also calcium in its composition. The present findings agree with other studies in which different bioactive glasses provided a favorable situation for cells (12) to promote differentiation and to support significantly larger areas of calcified matrix. In the same way, Matsuda and Davies (21) showed a better cellular colonization and extracellular matrix production on bioactive glasses versus nonbioactive glasses in calvaria organ cultures. These results also revealed that the three-dimensionality interfered in the amount of calcium, differing from other studies, which considered that calcium deposition was significantly increased in 3D compared with $2 \mathrm{D}(22,23)$. Indeed, it has been demonstrated that the collagen calcium content was slightly affected by coating collagen on 2D, which is in accordance with another study (24). This fact may be explained by the absence of continuous cell renewal, which is a characteristic of the used in vitro system, leading to a reduction in the population of active osteoblasts during the mineralization phase (25).

The results showed that the three-dimensionality and BG particles supported the cellular viability and differentiation, ALP activity, mineralized nodules formation and favored the genic expression characteristic of osteoblastic phenotype when cultured on 3D collagen type and osteogenic conditions. However, the distribution of cells and BG particles in the scaffolds needs to be further investigated, as it plays an important role on cell activities and the differentiation study.

\section{Resumo}

0 objetivo deste estudo foi investigar a influência do modelo de cultura celular tridimensional e das partículas de vidro bioativo (BG) sobre a expressão fenotípica de culturas de células osteogênicas da calvária de ratos. As células foram mantidas em culturas sobre superficies colágenas bi-dimensionais (2D) e em géis de colágeno tridimensional (3D) com e sem partículas de BG até 14 dias. Foram avaliadas: viabilidade celular, atividade de fosfatase alcalina (ALP), morfologia celular e imunomarcação de proteínas da matriz não-colágena do osso através de epifluorescência e microscopia confocal. As expressões de marcadores osteogênicos foram analisadas utilizando RT-PCR. A formação de nódulos mineralizados foi visualizada através de microscopia e o conteúdo de cálcio foi avaliado quantitativamente pelo Alizarina Red. As culturas experimentais produziram uma taxa crescente de viabilidade até 14 dias. Embora a atividade ALP em 7 dias tenha sido maior em culturas com BG, as células em 3D e 3D+BG apresentaram uma diminuição da atividade ALP aos 14 dias. As condições tridimensionais favoreceram a imunomarcação para OPN e BSP e a expressão de mRNAs para ALP e COL I. As partículas de BG influenciaram positivamente a expressão do mRNAs para OPN e OC e a formação de nódulos calcificados in vitro. Os resultados indicaram que as culturas em 3D e partículas BG contribuíram para a expressão do fenótipo osteoblástico e para a diferenciação e formação de matriz mineralizada.

\section{Acknowledgements}

This study was supported by the São Paulo State Research Foundation (FAPESP, Brazil).

\section{References}

1. Owen TA, Aronow M, Shalhoub V, Barone LM, Wilming L, Tassinari MS, et al.. Progressive development of the rat osteoblast phenotype in vitro: reciprocal relationships in expression of genes associated with osteoblast proliferation and differentiation during formation of the bone extracellular matrix. J Cell Physiol 1990;143:420-430.

2. Facer SR, Zaharias RS, Andracki ME, Lafoon J, Hunter SK, Schneider GB. Rotary culture enhances pre-osteoblast aggregation and mineralization. J Dent Res 2005;84:542-547

3. Lee $\mathrm{CH}$, Singla $\mathrm{A}$, Lee Y. Biomedical applications of collagen. Int J Pharm 2001;221:1-22.

4. Radin S, Reilly G, Bhargave G, Leboy PS, Ducheyne P. Osteogenic effects of bioactive glass on bone marrow stromal cells. J Biomed Mater Res 
A 2005;73:21-29.

5. Mosmann T. Rapid colorimetric assay for cellular growth and survival: application to proliferation and cytotoxicity assays. J Immunol Methods 1983;65:55-63.

6. Lowry $\mathrm{OH}$, Rosebrough NJ, Farr AL, Randall RJ. Protein measurement with the Folin phenol reagent. J Biol Chem 1951;93:265-275.

7. Livak KJ, Schmittgen TD. Analysis of relative gene expression data using real-time quantitative PCR and the 2(-Delta Delta $C(T))$. Methods 2001;25:402-408.

8. Gregory CA, Gunn WG, Peister A, Prockop DJ. An Alizarin red-based assay of mineralization by adherent cells in culture: comparison with cetylpyridinium chloride extraction. Anal Biochem 2004:329:77-84.

9. Naito H, Dohi Y, Zimmermann WH, Tojo T, Takasawa S, Eschenhagen T, et al.. The effect of mesenchymal stem cell osteoblastic differentiation on the mechanical properties of engineered bone-like tissue. Tissue Eng Part A 2011;17:2321-2329.

10. Ozawa $R$, Yamada $Y$, Nagasaka $T$, Ueda M. A comparison of osteogenesis-related gene expression of mesenchymal stem cells during the osteoblastic differentiation induced by type-I collagen and/ or fibronectin. Int J Oral Med Sci 2003;1:139-146.

11. Velazquez OC, Snyder R, Liu ZJ, Fairman RM, Herlyn M. Fibroblastdependent differentiation of human microvascular endothelial cells into capillary-like 3-dimensional networks. FASEB J, 2002;16:13161318.

12. Loty C, Sautier JM, Tan MT, Oboeuf M, Jallot E, Boulekbache $H$, et al.. Bioactive glass stimulates in vitro osteoblast differentiation and creates a favorable template for bone tissue formation. J Bone Miner Res 2001;16:231-239.

13. Lian JB, Stein GS. Concepts of osteoblast growth and differentiation: basis for modulation of bone cell development and tissue formation. Crit Rev Oral Biol Med 1992;3:269-305.

14. Berthod F, Hayek D, Damour O, Collombel C. Collagen synthesis by fibroblasts cultured within a collagen sponge. Biomaterials 1993;14:749-754.

15. Kale S, Biermann S, Edwards C, Tarnowski C, Morris M, Long MW. Threedimensional cellular development is essential for ex vivo formation of human bone. Nat Biotechnol 2000;18:954-958.
16. Trojani $C$, Weiss $P$, Michiels JF, Vinatier $C$, Guicheux J, Daculsi $G$, et al. Three-dimensional culture and differentiation of human osteogenic cells in an injectable hydroxypropylmethylcellulose hydrogel. Biomaterials 2005;26:5509-5517.

17. Boukhechba F, Balaguer T, Michiels JF, Ackermann K, Quincey D, Bouler $J M$, et al.. Human primary osteocyte differentiation in a 3D culture system. J Bone Miner Res 2009;24:1927-1935.

18. Varanasi VG, Saiz E, Loomer PM, Ancheta B, Uritani N, Ho SP, et al.. Enhanced osteocalcin expression by osteoblast-like cells (MC3T3-E1) exposed to bioactive coating glass $\left(\mathrm{SiO}_{2}-\mathrm{CaO}-\mathrm{P}_{2} \mathrm{O}_{5}-\mathrm{MgO}-\mathrm{K}_{2} \mathrm{O}-\mathrm{Na}_{2} \mathrm{O}\right.$ system) ions. Acta Biomater 2009;5:3536-3547.

19. Yefang Z, Hutmacher DW, Varawan SL, Meng LT. Comparison of human alveolar osteoblasts cultured on polymer-ceramic composite scaffolds and tissue culture plates. Int J Oral Maxillofac Surg 2007;36:137-145.

20. Huang JC, Sakata T, Pfleger LL, Bencsik M, Halloran BP, Bikle DD, et al.. PTH differentially regulates expression of RANKL and OPG. J Bone Miner Res 2004;19:235-244.

21. Matsuda T, Davies JE. The in vitro responses of osteoblasts to bioactive glass. Biomaterials 1987;8:275-284.

22. Nakamura $A$, Dohi $Y$, Akahane $M$, Ohgushi $H$, Nakajima $H$, Funaoka $H$, et al.. Osteocalcin secretion as an early marker of in vitro osteogenic differentiation of rat mesenchymal stem cells. Tissue Eng Part C Methods 2009;15:169-180.

23. Komori T. Regulation of skeletal development by the Runx family of transcription factors. J Cell Biochem 2005;95:445-453.

24. Becker D, Geissler U, Hempel U, Bierbaum S, Scharnweber D, Worch $\mathrm{H}$, et al.. Proliferation and differentiation of rat calvarial osteoblasts on type I collagen-coated titanium alloy. J Biomed Mater Res 2002;59:516-527.

25. Assis AF, Beloti MM, Crippa GE, Oliveira PT, Morra M, Rosa AL. Development of the osteoblastic phenotype in human alveolar bonederived cells grown on a collagen type I-coated titanium surface. Clin Oral Implants Res 2009;20:240-246.

Received October 20, 2016 Accepted March 14, 2017 